\title{
STRUCTURAL ANALYSIS OF EVOLUTIONS IN AGRICULTURAL ACTIVITIES IN RURAL AREAS: THE CASE OF MARKAZI PROVINCE IN CENTRAL IRAN
}

\author{
Siamak Zabihi' ${ }^{1}$, Seyed Jamal Farajollah Hosseini ${ }^{2}$, Seyed Mehdi Mirdamadi ${ }^{3}$, Abbas Amini ${ }^{4}$ \\ ${ }^{I}$ Ph.D. Student, Department of Economic, Agricultural Extension and Education, Science and Research Branch, Islamic \\ Azad University, Tehran, Iran. E-mail address: s-zabihi@iau-arak.ac.ir \\ ${ }^{2}$ Associate Professor, Department of Economic, Agricultural Extension and Education, Science and Research Branch, \\ Islamic Azad University, Tehran, Iran. E-mail address: jamalfhosseini@yahoo.com \\ ${ }^{3}$ Associate Professor, Department of Economic, Agricultural Extension and Education, Science and Research Branch, \\ Islamic Azad University, Tehran, Iran. E-mail address: mirdamadi.mehdi@gmail.com \\ ${ }^{4}$ Associate Prof. of Geography and Rural Planning, Dept. Geographical Sciences and Planning, University of Isfahan, \\ Isfahan.E-mail address: a.amini@geo.ui.ac.ir
}

Received 1911 2020; Accepted 08012021

\begin{abstract}
This study considers the evolutionary trend of agricultural functionalities in rural areas of Markazi Province in central Iran over the last decade. The province is the most and heavily industrialized region across the country, accomplished with urbanized settling and life style and declination in rurality, both functionally and structurally. This study aims to evaluate the evolutions of agricultural functionalities in rural areas of the region. All of the villages more populated than 20 households in during 2003 and 2014 were studied. The similar agricultural variables in the two time periods were utilized as data set and 10 indicators for each section were defined, calculated, and considered. Followed by the statistical description and examining the distributions of the indicators, the evolution of agricultural activities in the region was separately modelled for each of time sections through Structural Equation Modeling. The path structure of the first model revealed that the agricultural functionality of the studied area has at the beginning time mainly been based on farming - rather than gardening - and based on land resources - rather than water resources. As well, the results of the ending model indicated that land has been replaced by water. Also, the declining trend of changes during the studied period was significantly influenced by water. Therefore, it is absolutely essential to establish an integrated organizational structure for policy regulation and decision-making for land and water resources, along with a provincial governance to implement the policies and decisions beyond the sectoral approach. This could possibly help to mitigate the problems encountered by the agricultural sector in rural communities of the study area.
\end{abstract}

Key words: Agricultural Functionality, Structural Equation Modeling (SEM), Rural Communities, Markazi Province, Central Iran.

JEL Codes: C100, C650, Q100, Q150, R110, R140.

\section{Introduction}

Rural areas, as a significant part of every society in every country, play a critical role in national and rural development. For people living in cities, rural areas are best known as an antithesis to urban life (Rousseau 1995).
However, these areas have encountered some major challenges for survival due to uncoordinated policies, widespread and rapidly evolving industries, and technological developments over time (Zabihi et al. 2019).

Copyright $\odot 2021$ Author(s), published by Vytautas Magnus University. This is an open access article distributed under the terms of the Creative Commons Attribution Non-Commercial 4.0 (CC BY-NC 4.0) license, which permits unrestricted use, distribution, and reproduction in any medium provided the original author and source are credited. The material cannot be used for commercial purposes. 
In this regard, certain issues have been considered such as redefinition of natural landscapes and open environments, agricultural restructuring, re-creation of rural and residential landscapes, re-associability and land use change, destruction of natural landscapes, and de-urbanization of rural areas (Khosrowbeygi Borchaloei 2016). The most fundamental problem in rural communities is the destruction of villages and the evasion of their population. Thus, an important question arises as to the reasons behind why the villages disappear and the potential factors which affect it. It is noteworthy that each function comes from a structure, causing a place function like a village, and could be explored from the human and environmental dimensions. As for the environmental dimension, unprecedented changes in rural areas and their inhabitants are largely due to the role and function of the agricultural sector that has traditionally been the main motivation for evolution (Eupen et al. 2012).

Anríquez and Stamoulis (2007) maintain that although the practical importance of agriculture in the national economy might decrease under evolution, it does not necessarily mean its importance in rural economy can decrease. Rural areas have experienced several continuous changes in some aspects such as social, physical, and spatial composition (Paquette and Domon 2003). The European Commission considers rural areas as complex economic, natural, and cultural sites, which cannot be distinguished by only one single criterion (Gulumser et al. 2006). In the present era, rural areas are undergoing unprecedented changes due to the constant flow of labor, capital, and technology (Moutafi 2013).

It is worth noting that the existing changes in the rural areas and their inhabitants have been largely caused by the changes in the role and function of the agricultural sector (Eupen et al. 2012). The Handbook on United Nations Rural Households and Welfare (2007) outlines two sectoral and territorial approaches to choose some aspects of rural communities. In this regard, the sectoral approach is mostly used in developing countries where the rurality concept is exclusively related to agriculture, forestry, and fishing (Johansen and Nielsen 2012). The other conceptualization of rural communities is geographical (territorial \& spatial). In this approach, although demographic features such as population density, size, and spatial ranges play an essential role in defining rural communities, it seems that the population density is an inadequate or, at least, partial indicator for defining the rural communities (Balestrieri 2014).

According to Gulumser et al. (2006), the term rural area is essentially employed as a place for agricultural activity to identify the areas that are not urban. Berry et al. (2010) investigated several conceptual approaches to rural communities and concluded that although both rural and agricultural sectors are conventionally interrelated, agriculture is knows as a critical factor differentiating what is rural and urban. Paquette and Domon (2003) found that the remarkable diversity of rural areas has led to the increased disparity between agriculture and demography. Eupen et al. (2012) provided a rural typology capable of recognizing the similarities of rural areas and their internal grading. Li et al. (2015) explored the relationship between rural community indicators and major economic, social, and geographical indicators in China's rural communities using the census data of 2000 and 2010. Pizzoli (2015) concluded the obtained data from the statistical offices could enable the calculation of referrals related to the rural communities. Finally, Peng et al. (2016) addressed a key aspect of the rural communities formed by land use, self-sufficiency, production, and employment.

In the field of agriculture-rural communication, the most crucial issue is the role and task of the agriculture sector as a major economic factor in rural areas, which has contributed to the instability and decline of the 
Management Theory and Studies for Rural Business and Infrastructure Development

eISSN 2345-0355. 2021. Vol. 43. No. 3: 390-402

Article DOI: https://doi.org/10.15544/mts.2021.36

rural settlements and the high motivation to leave the villages (Latifeh et al. 2016). According to the general population census data in Iran, the proportion of rural settlements has increased from $68.6 \%$ in 1956 to $25.9 \%$ in 2016 (Statistical Center of Iran 2018). In terms of evolution of agricultural activities, Markazi Province ranks the $18^{\text {th }}$ while its degree of evolution of agricultural activities is 0.342 lower than the national average (Karami and Rastegari 2018). The percentage of rural population in Markazi province in 2016 was $23.1 \%$ below the national average. The population used in its agricultural sector fell $12.8 \%$ over ten years according to the agricultural census of 2014, compared to the 2003 census, which declined by $12.8 \%$ only during ten years, while the average annual growth of the rural population in this province has negatively increased in recent years (Statistical Center of Iran 2018). Here, any potential plan and solution to cope with the aforementioned challenges logically requires a scientific and careful examination of several dimensions and components.

The main objective of the present study is to explore the evolution of agricultural activities in rural areas of Markazi province in Iran over a decade with a particular emphasis on agricultural functions. The province is the most and heavily industrialized region across the country. While the overall provincial population is, based on the official data from sequential Population and Housing Censuses, grown over recent decades, the rural population is declined for the urban population. As presented in Table 1 and depicted in Fig. 1, the huge gap between the rural and urban population for the rural one has been reversed for urban through recent decades, so that the rapid urbanization trend and dominance of urban life style has accomplished with declination of rurality, both in demographic structures and environmental and productive functionalities as well. Therefore, the evolution of agricultural functionalities over time is considered a key aspect in this study. In this vein, while compiling the agricultural indicators for the rural communities, the basic question is how the evolutions of agriculture have been in rural communities in Markazi province. Therefore, the study does not attempt to define the rural or how it differentiates with the urban. Instead, the matter that the paper focused on, is to represent the status of agricultural functionality as an important component of rurality and its evolution over a decade across the rural territories of the Markazi province in Iran, which are well known as village on behalf of the Statistical Center of Iran and in common language and documented in official Censuses of Population and Housing.

Table1. Population changes of the study area over 1956-2016 in rural and urban sectors

\begin{tabular}{|c|c|c|c|c|c|}
\hline \multirow[b]{2}{*}{ Year (Census) } & \multirow[b]{2}{*}{ Total Population } & \multicolumn{2}{|l|}{ Urban } & \multicolumn{2}{|l|}{ Rural } \\
\hline & & Population & Pct. & Population & Pct. \\
\hline 1956 & 600455 & 92530 & 15.41 & 507925 & 84.59 \\
\hline 1966 & 688046 & 124838 & 18.14 & 563208 & 81.86 \\
\hline 1976 & 786291 & 213586 & 27.16 & 572705 & 72.84 \\
\hline 1986 & 1082109 & 476127 & 44.00 & 605982 & 56.00 \\
\hline 1996 & 1228812 & 701547 & 57.09 & 527265 & 42.91 \\
\hline 2006 & 1351257 & 932073 & 68.98 & 419184 & 31.02 \\
\hline 2016 & 1429457 & 1099767 & 76.94 & 329690 & 23.06 \\
\hline
\end{tabular}

*(Source: Statistical Center of Iran, 1956-2016) 


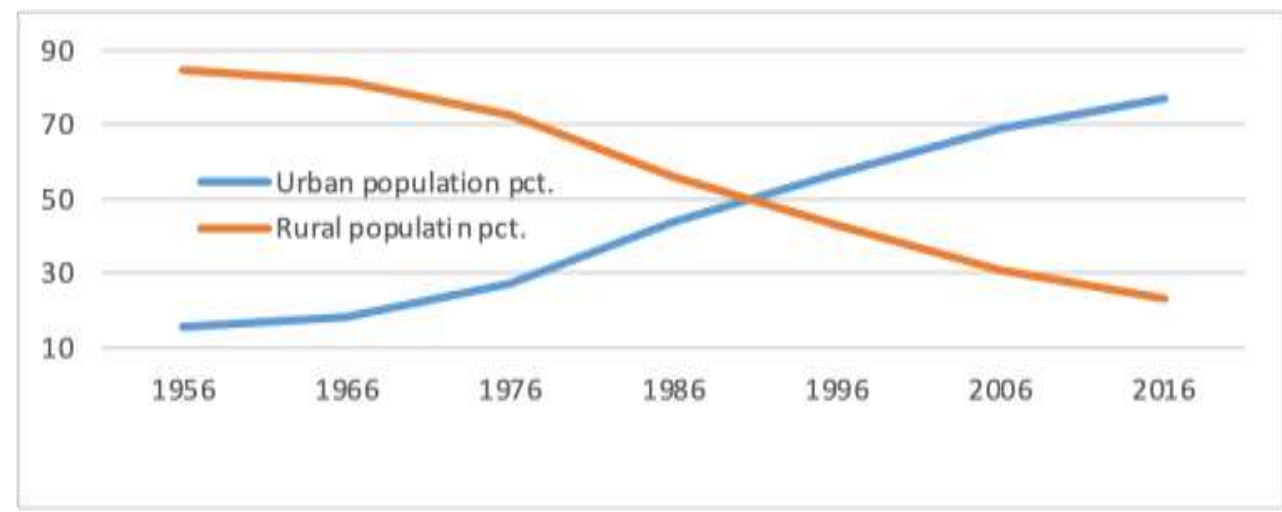

Figure 1. The reverse trend of rural population declines and urban population growth in study area

\section{Materials and Methods}

This study was descriptive-analytical, and descriptive and inferential statistics were used to analyze the data. Regarding different dimensions of each phenomenon, there were no independent and dependent variables, indicating that all variables can be considered both independent and dependent. The statistical description and evaluation of the distribution of indicators, as well as modeling of agricultural structure in the rural areas were conducted through structural equation based on Bootstrapping approach using SPSS and Amos Graphic software. This method is performed based on sampling by placing a sample from the mother or the original (733 villages were studied here) repeatedly. The statistical population and geographical area included all villages in the top 20 households of Markazi province, based on the data collected in two Censuses of Agriculture in 2003 and 2014, performed by Statistical Center of Iran, in which the unit of analysis in this study is the village. After choosing and matching the villages in the two sections and removing non-rural census areas and militaries including military centers, companies, manufacturing units, and workshop units, the statistical sample of the study consisted of 733 villages with more than 20 households in both sections (Table 2).

Table 2. The geographical distribution and number of villages with more than 20 households Statistical Center of Iran, 2016 (Population and Housing Census)

\begin{tabular}{llllll}
\hline County & $\begin{array}{l}\text { Number of } \\
\text { rural districts }\end{array}$ & $\begin{array}{l}\text { Number of } \\
\text { studied villages }\end{array}$ & County & $\begin{array}{l}\text { Number of rural } \\
\text { districts }\end{array}$ & $\begin{array}{l}\text { Number of } \\
\text { studied villages }\end{array}$ \\
\hline Ashtian & 3 & 26 & Delijan & 3 & 20 \\
Arak & 11 & 85 & Zarandieh & 6 & 44 \\
Tafresh & 4 & 54 & Saveh & 7 & 86 \\
Khomein & 7 & 99 & Shazand & 9 & 152 \\
Khondab & 5 & 66 & Farahan & 4 & 50 \\
Komijan & 4 & 38 & Mahalat & 2 & 13 \\
Total & & & 12 & 65 & 733 \\
\hline
\end{tabular}


Management Theory and Studies for Rural Business and Infrastructure Development

eISSN 2345-0355. 2021. Vol. 43. No. 3: 390-402

Article DOI: https://doi.org/10.15544/mts.2021.36

The employed variables included the maximum valid related items in both censuses, which were separately extracted but completely similar in the villages.

The fourteen final validated variables for each of the two sections were as follows:

1. The whole number of agricultural stakeholders;

2. The number of inhabiting (resident) stakeholders;

3. The number of literate stakeholders;

4. The number of land-related agricultural operating systems;

5. The number of land-related agricultural farming systems;

6. The number of land-related agricultural orchard (gardening) systems;

7. The area of land-related agricultural operating systems (total area of arable lands);
8. The area of irrigated agricultural operating systems (total area of irrigated lands);

9. The area of rain-fed agricultural operating systems (total area of rainfed arable lands);

10. The area of land-related agricultural orchard systems (total orchards' area);

11. The area of arable agricultural farming systems (total area of arable farms);

12. The area of cultivated agricultural farming systems (total area of cultivated farms);

13. The area of irrigated cultivated agricultural farming systems (total area of irrigate cultivated farms);

14. The area of rain-fed cultivated agricultural farming systems (total area of rain-fed cultivated farms).

Data processing and indexing were performed based on the final variables (Table 3) and explained below.

Table 3. The defined indicators for the status of agricultural functionalities at the beginning and end of the study period

\begin{tabular}{|c|c|c|}
\hline \multicolumn{2}{|c|}{$\begin{array}{l}\text { Indicators } \\
\text { (Defined based on the relevant variables) }\end{array}$} & \multirow{2}{*}{$\begin{array}{l}\begin{array}{l}\text { Abbreviations } \\
\text { (in the model) }\end{array} \\
\text { Stakeholder Families Pct. }\end{array}$} \\
\hline 1 & The rate of agricultural employment among rural households & \\
\hline 2 & The rate of literate farmers & Literate Stakeholders Pct. \\
\hline 3 & The percentage (pct.) of farming agricultural systems & Farming Stakeholders Pct. \\
\hline 4 & The percentage (pct.) of orchard agricultural systems & Garden Stakeholders Pct. \\
\hline 5 & Stakeholders' mean farm area & Stak. Mean farm area \\
\hline 6 & Household farm area per capita & Per cap. Famil. Farm Area \\
\hline 7 & The percentage (pct.) of irrigated lands & Irrigate Stak. Area Pct._82 \\
\hline 8 & Percentage (pct.) of orchard farms in the agricultural systems & Garden Stak. Area Pct. 82 \\
\hline 9 & The percentage (pct.) of cultivated lands (land intensification) & Intensity Rate \\
\hline 10 & The percentage (pct.) of irrigated cultivated lands & Irrigated Cultivation Pct. \\
\hline
\end{tabular}

Accordingly, the evolution indicators were collected based on the difference between the indicators at the end of 2014 and at the beginning of the period (2003) in each village to the absolute value of the corresponding difference across the whole province (all investigated villages).

Markazi province is located in the central plateau of Iran. According to the latest data from the Statistical Centre of Iran, this province 
has 12 counties, 23 districts, 33 cities, 66 rural districts, and 1208 villages with 1429475 populations, $1099764(76.9 \%)$ in urban areas and $329690(23.1 \%)$ in rural areas (Statistical Center of Iran, 2018). In terms of the geographical and climatic conditions and Significant productive land and water resources and fertility, it is one of the most important agricultural and livestock areas in the country (Statistical Yearbook of Markazi Province, 2015).

\section{Results and Discussion}

The structural model of agricultural functionalities in rural areas of Markazi province in 2003 (the beginning of the study period)

The Agricultural Status Measurement Scale of Rural Areas in 2003 (i.e. at the beginning of the study period) was conducted using Confirmatory Factor Analysis (CFA) with ten relevant indicators using AMOS Graphics software. The best model was specified among the possible models using accurate search tools by considering the maximum of all ten indicators of agricultural status measurement model. Figure 2 shows the final model along with the standard estimates of the path coefficients, as well as different types of the goodness of fit index (GFI) models based on the autonomy approach.

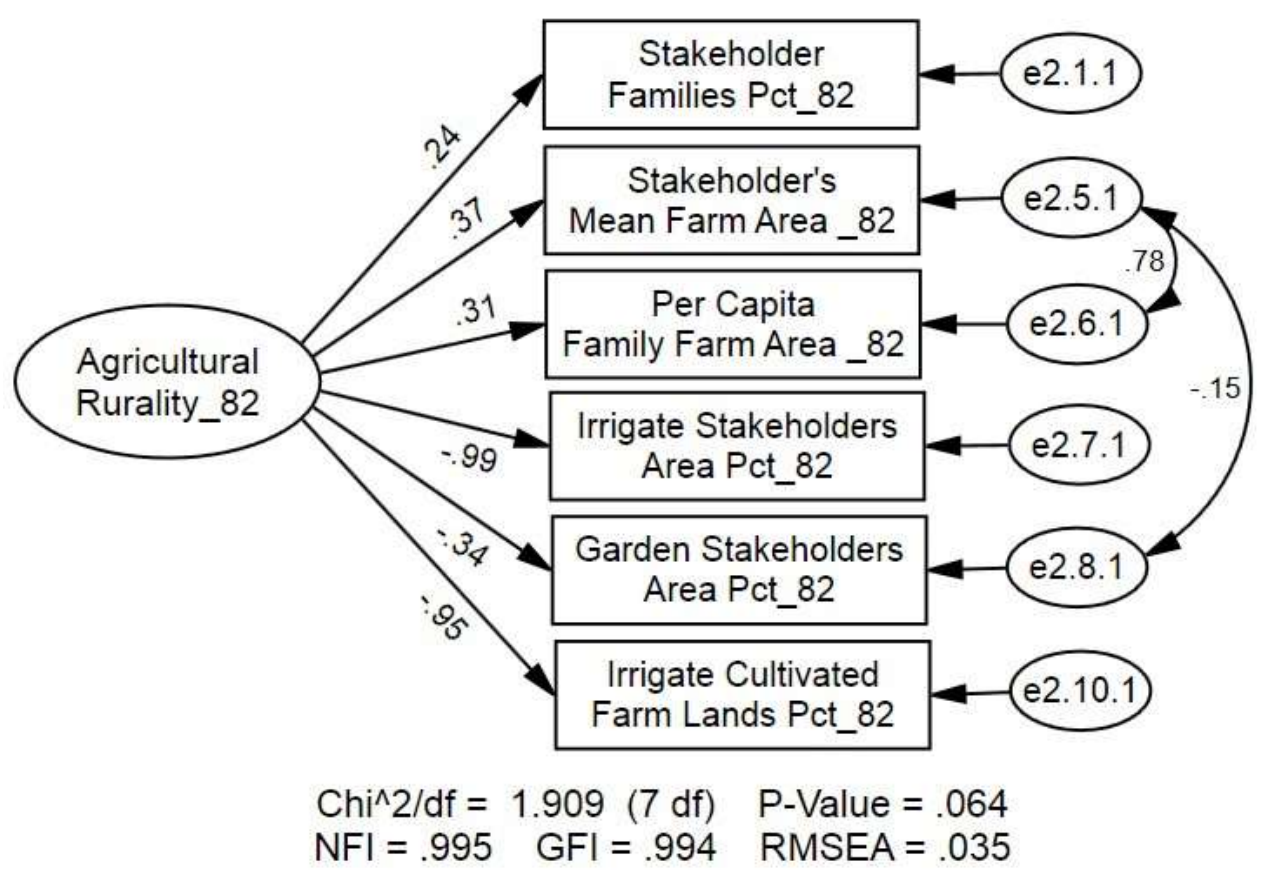

Figure 2. Rural agricultural status measurement model of 2003 along with the standard estimates and its validation indicators 


\section{sciendo}

Management Theory and Studies for Rural Business and Infrastructure Development

eISSN 2345-0355. 2021. Vol. 43. No. 3: 390-402

Article DOI: https://doi.org/10.15544/mts.2021.36

As observed, the rate status of literate stakeholders, number of land-related agricultural farming systems, number of landrelated agricultural orchard (gardening) systems, and size changes of stakeholder's land use are not included in the final model. All three groups of fitting indicators (chi-square with a small value of 1.9, degree of freedom 7, and significance level of 0.064 and GFI with a value of about 0.994), NFI comparative fitting indicators with a value of about one, 0.995 . while the RMSEA (Root Mean Square Error of Approximation) with the values close to 0.035, all of which confirm the high validity of the model and its good fitness to the collected data. In addition to the provided standard coefficients in Figure 2, Table 4 also shows the coefficients for the remaining variables in the final model in both the standard and nonstandard form along with standard error, critical ratio, and significant level.

Table 4. Regression estimates of the components of rural agricultural status scale of the province in 2003

\begin{tabular}{llllll}
\hline $\begin{array}{l}\text { Measured components and variables } \\
\text { (Observed variables) }\end{array}$ & \multicolumn{2}{l}{ Regression weights } & & \\
\cline { 2 - 3 } & Non-standard & Standard & Critical Ratio & S.E. & Sig. \\
\hline Agricultural employment rate & 1 & 0.24 & & 0.16 & 0.00 \\
Cultivated lands (land intensification) & 0.89 & 0.37 & 5.61 & 0.20 & 0.00 \\
Household farm area per capita & 1.02 & 0.31 & 5.29 & 1.30 & 0.00 \\
Irrigated lands & -8.63 & -0.99 & -6.62 & 0.20 & 0.00 \\
Orchard farms in agricultural systems & -0.99 & -0.34 & -5.02 & 0.00 \\
Irrigated cultivated lands & -8.54 & -0.95 & -6.61 & 0.00 \\
\hline
\end{tabular}

Component values of agricultural employment rate are not reported because this variable is denoted as a reference to measure the scale of rural agricultural status in order to eliminate it without any unit of measurement (Ghasemi 2010). The comparison of the path coefficients and positive signs of the three indicators cultivated against cultivable lands (land intensification), household farm area per capita, and agricultural employment rate (with standard regression weights of $0.37,0.31$, and 0.24 ) with the path coefficients and negative signs of the three indicators irrigated land, irrigated cultivated lands, and the status of orchard farms in agricultural systems (with standard regression weights of $-0.99,-0.95$, and -0.34 ) indicates that the agricultural status of the villages in Markazi province was mostly based on farming rather than gardening, in 2003. In the other word, it was mostly based on the land, rather than wate.

The structural model of agricultural functionalities in rural areas of Markazi province in 2014 (the end of the study period)

Considering the maximum of all ten indicators of Agricultural Status Measurement Model at the end of the period by utilizing the exact search tool, the Agricultural Status Measurement Scale of Rural Areas in 2014 (end of the study period) was confirmed as the best model among all other possible models. 


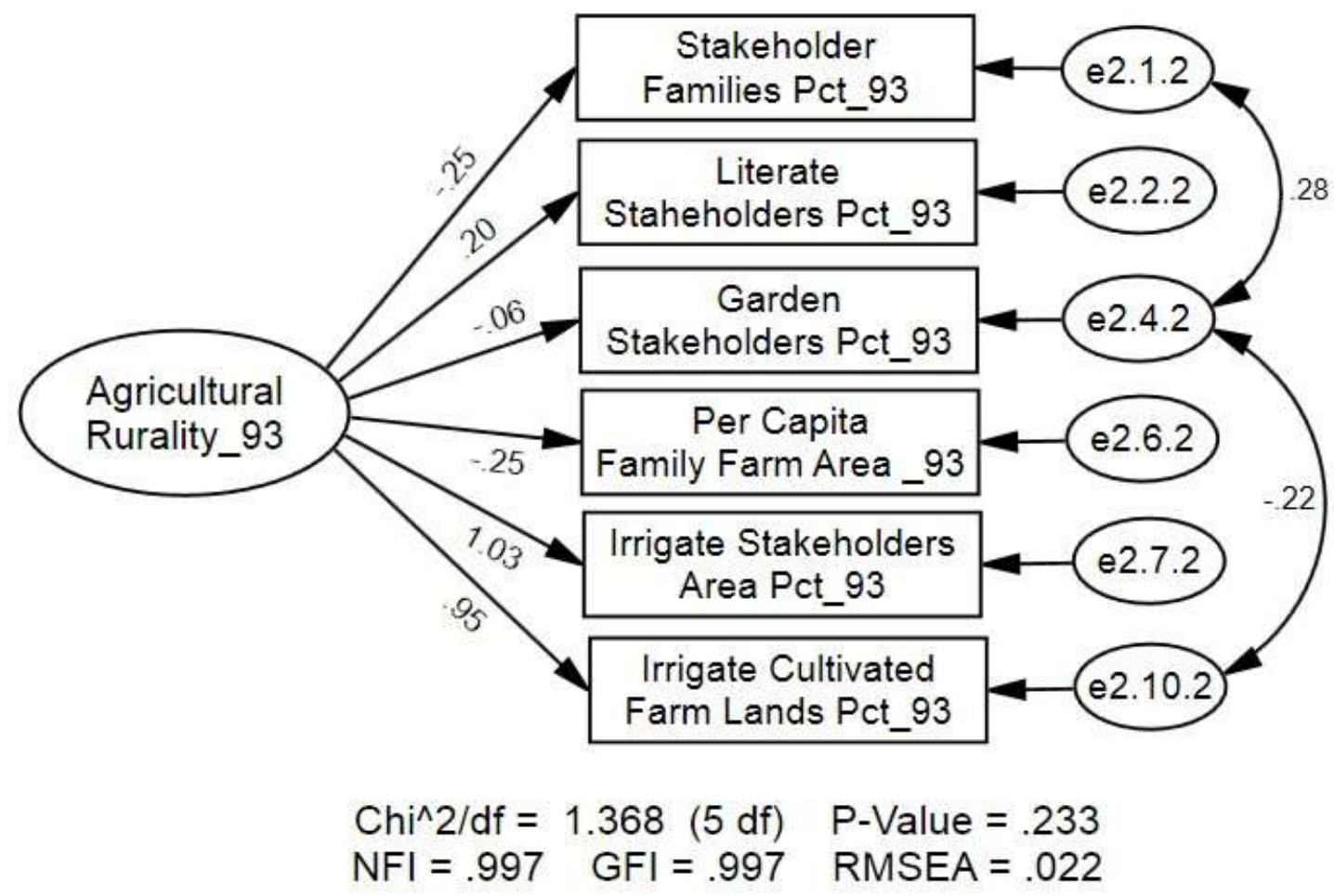

Figure 3. Rural agricultural status measurement model of 2014 with standard estimates and validation indicators

As can be observed, the number of landrelated agricultural farming systems, the size of land-related agricultural operating systems (total area of arable lands), the area of land-related agricultural orchard systems (total orchard area), and the number of land-related agricultural farming systems are not present in the final model. The indicator household farm area per capita remains in this composition, indicating its role and importance in the agricultural status of the villages in Markazi province. Ultimately, all three groups of the indicators such as fitting absolute, comparative, and economical (chi-square with a small value of 1.36, degree of freedom 5, at the significance level of 0.23 , GFI and NFI both with a value close to 0.997 and the RMSEA with a value close to zero, i.e. 0.022) confirm the high validity of the model and its good fitness to the data collected. Table 5 shows the coefficients for the remaining variables in the final model, in both standard and nonstandard form, along with the standard errors, critical ratios, and the significance levels. 


\section{sciendo}

Management Theory and Studies for Rural Business and Infrastructure Development

eISSN 2345-0355. 2021. Vol. 43. No. 3: 390-402

Article DOI: https://doi.org/10.15544/mts.2021.36

Table 5. Regression estimates of components of rural agricultural status scale in 2014

\begin{tabular}{llllll}
\hline \multirow{2}{*}{$\begin{array}{l}\text { Measured components and variables } \\
\text { (Observed variables) }\end{array}$} & \multicolumn{2}{l}{ Regression weights } & & \\
\cline { 2 - 4 } & Non-standard & Standard & Critical Ratio & S.E. & Sig. \\
\hline Agricultural employment rate & -0.14 & -0.25 & 5.69 & 0.01 & 0.00 \\
Literate farmers rate & 0.07 & 0.20 & -7.25 & 0.02 & 0.00 \\
Stakeholders' mean farm area & -0.05 & -0.06 & -1.72 & 0.03 & 0.08 \\
Household farm area per capita & -0.12 & -0.25 & -7.29 & 0.02 & 0.00 \\
Irrigated lands & 1.06 & 1.03 & 35.97 & 0.03 & 0.00 \\
Irrigated cultivated lands & 1.00 & 0.95 & & & \\
\hline
\end{tabular}

Careful consideration of the path coefficients and their signs indicates that gardening did not play any significant role in the agricultural changes in Markazi province due to its negative and non-significant coefficients in the cultivation pattern $(-0.06)$ such as in 2003. Nevertheless, a significant difference was observed between two patterns in two sections. At this point, the indicators related to the water including the percentage of the irrigated land with the positive regression weight of 1.03 played a more essential role in the agricultural status of the rural areas compared to the percentage of the stakeholders' area with irrigated land under cultivation (total irrigated land under cultivation) with the positive regression weight of 0.95 . In addition, compared with the model for the beginning of the period, the determination and importance of the land have given way to irrigated land under cultivation.

\section{Structural analysis of evolution of agricultural activities during 2003-2014.}

The rural evolution measurement scale of rural provinces during 2003-2014 was conducted based on Confirmatory Factor Analysis (CFA) of ten related indicators. As shown, the goodness-of-fit indices of this model show that it is close to $100 \%$. 


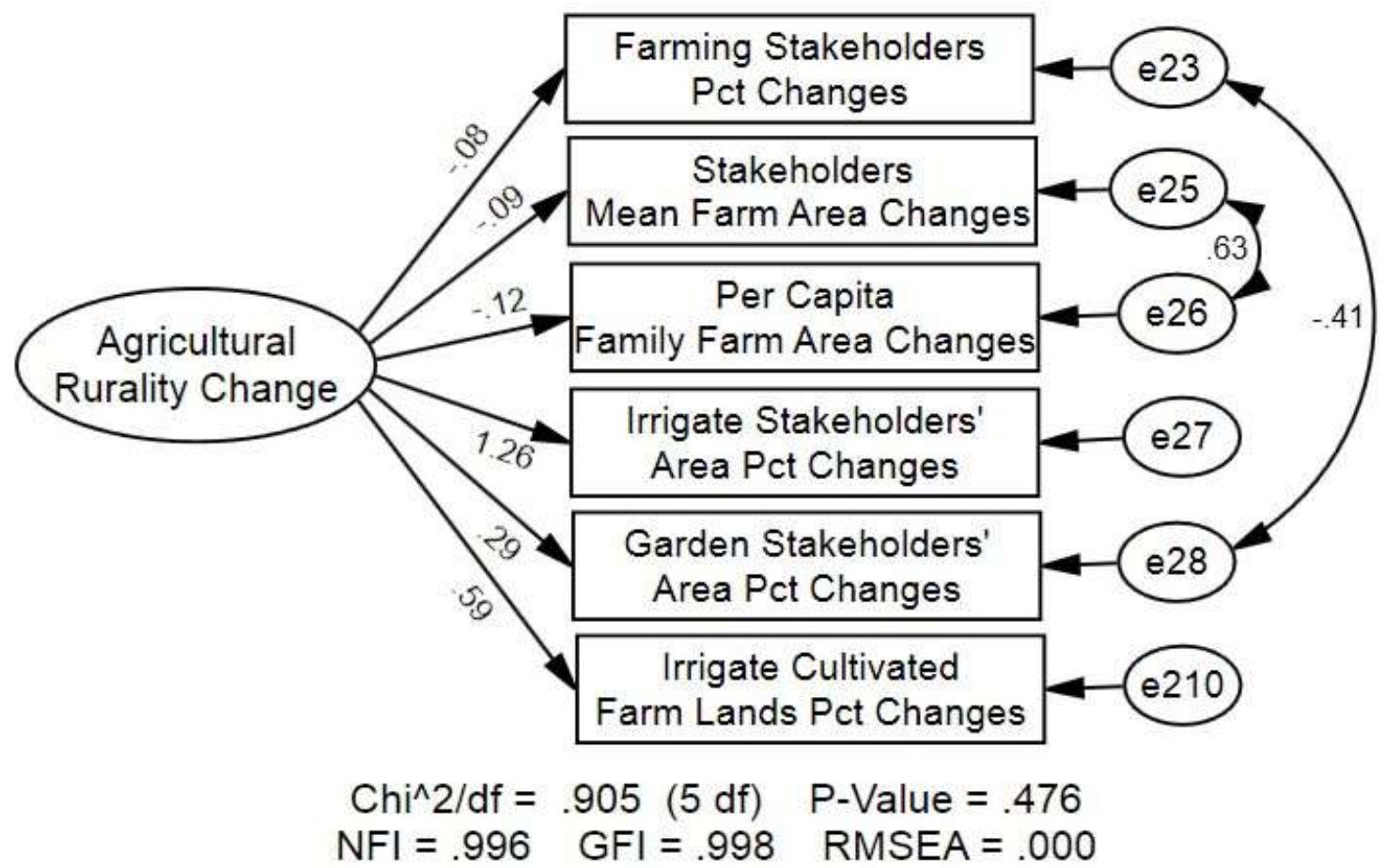

Figure 4. The measurement model for the evolution of agricultural activities in Markazi province villages during 2003-2014 with standard estimates and validation indicators

In the final combination of the measurement model for the evolution of agricultural activities, although the six indicators of the percentage (pct.) of farming agricultural systems, the mean farm area, family farm area per capita, changes in irrigated land, the area of land-related agricultural orchard systems (total orchards' area), changes in the area of irrigated cultivated agricultural farming systems (total area of irrigated cultivated farms) had significant path coefficients, which are almost negligible in the first two cases. To gain a better understanding of the nature of evolution of agricultural activities in the rural areas during the period, Table 6 indicates the value, sign, and significance level of the standard estimates of the model path coefficients, as well as the mean value and sign of the indicators.

Table 6. Regression estimates of components of rural agricultural status scale of the province during 2003-2014

\begin{tabular}{|c|c|c|c|c|c|c|}
\hline \multirow{2}{*}{$\begin{array}{l}\text { Measured components and variables } \\
\text { (Observed variables) }\end{array}$} & \multirow[b]{2}{*}{ Average } & \multicolumn{2}{|c|}{ Regression weights } & \multirow[b]{2}{*}{ Critical Ratio } & \multirow[b]{2}{*}{ S.E. } & \multirow[b]{2}{*}{ Sig. } \\
\hline & & Non-standard & standard & & & \\
\hline pct. of farming in agricultural systems & -5.71 & -0.12 & -0.08 & -2.73 & 0.04 & 0.00 \\
\hline Stakeholders' mean farm area & 0.55 & -0.08 & -0.09 & -3.30 & 0.02 & 0.00 \\
\hline Household farm area per capita & 1.48 & -0.09 & -0.12 & -4.45 & 0.02 & 0.00 \\
\hline pct. of the irrigated lands & -5.11 & 2.03 & 1.26 & 6.87 & 0.29 & 0.00 \\
\hline $\begin{array}{l}\text { pct. of orchard farms in agricultural } \\
\text { systems }\end{array}$ & 4.11 & 0.29 & 0.29 & 9.50 & 0.03 & 0.00 \\
\hline pct. of irrigate cultivated lands & -11.01 & 1.00 & 0.59 & & & \\
\hline
\end{tabular}


Management Theory and Studies for Rural Business and Infrastructure Development

eISSN 2345-0355. 2021. Vol. 43. No. 3: 390-402

Article DOI: https://doi.org/10.15544/mts.2021.36

Based on the accuracy of mean and coefficients of indicators, the main role of evolution of agricultural activities in the rural areas of Markazi province during 2003-2014 is related to the significant decreasing trend of irrigated cultivation (Mean $=-11.01$, regression weight $=0.59)$, irrigated lands $($ Mean $=-5.11$, regression weight $=1.26)$, and stakeholders' mean farm area (Mean $=-5.71$, regression weight $=-0.08$ ), both simultaneously and on the upward trend. On the other hand, percentage (pct.) of orchard farms in the agricultural systems $($ Mean $=4.11$, regression weight $=0.29)$. Therefore, the declining trend of orchard farming in the agricultural systems was mostly affected by the irrigation water during this period.

\section{Conclusion}

The present study evaluated the evolution of agricultural activities in the rural areas of Markazi province. Based on the results, the situation of villages and rural status for agricultural activities has changed compared to the place they had before. In addition, a 13\% decrease occurred in the whole number of agricultural stakeholders over the two time periods in the present study. Further, these evolutions decreased in the number of inhabited (resident) stakeholders, number of land-related agricultural farming systems, and irrigated land. Based on the experimental results, the whole number of agricultural stakeholders increased from 9.5 to 10 hectares due to a decrease in the area of agricultural stakeholders between the two conducted censuses. Additionally, the area of stakeholders with irrigated land, agricultural stakeholders, and the area of irrigated agricultural operating systems (total area of irrigated lands) decreased during the studied period. In contrast, the evolutions of the area of land-related agricultural orchard systems (total orchard area)" increased by $4 \%$, while the ratio of cultivated against the cultivable lands, or the land intensification increased from $56 \%$ to $65 \%$.

The agricultural status of the rural areas in Markazi province was mainly based on farming,rather than gardening,due to the path coefficients and the positive sign of the three indicators number of land-related agricultural operating systems, household farm area per capita, and the rate of agricultural employment among rural households compared with the path coefficients and the negative sign of three indicators of irrigated land, irrigated cultivated land, and the area of land-related agricultural orchard systems (total orchard area). Further, it was mostly land-based rather than water-based. However, the obtained results of 2014 section could be attributed to the differences between the two models compared to the former section of 2003. In this period, the water-related indicators (i.e., the percentage of irrigated land stakeholders and the percentage of irrigated land in the cultivation pattern) played a critical role compared to the land factor in the status of agricultural rural areas, which is in line with the results of Berry et al. (2010).

Considering the mean and coefficients of the rural evolution indicators during 2003-2014, the significant decreasing trend of irrigated cultivated land, irrigated lands, and agricultural stockholders (Mean=11.01, 5.11, and 5.71, respectively) plays a main role in rural evolution in Markazi province, coinciding with the upward trend of the area of land-related agricultural orchard systems (total orchard area) in the cultivation pattern (Mean= 4.11). In addition, the evolution of agricultural activities in the villages was mostly affected by the irrigating water during this period, leading to variations in land use from high waterconsuming activities with fewer yields (farming) to low water-consuming ones and more yields (gardening).

The results are consistent with some other studies (e.g., Ebrahimpour 2004; Ghasemi 
Ardahaei 2008; Rezvani et al. 2011; Feli et al. 2012; Yousefi 2013; Latifeh et al. 2016; Khosrowbeygi Borchaloei 2016; Karami and Rastegari 2018).

According to Zabihi et al. (2019), the role of evolution of agricultural activities in rural evolution is more than the corresponding role of agricultural component at the beginning and end of the period due to the significant coefficients of indicators related to the changes in land and irrigated related factors in this model although the changes in rural areas of the province during the period were more influenced by demographic changes than in agricultural indicators. Over time, the rural areas in the province have become more adapted to the conditions and characteristics of the population, especially in harmony with age requirements, and rural population aging, as well as the changes in type stockholders of land. The results are in line with Paquette and Domon (2003), Li et al. (2015), and Guastella and Pareglio (2016).

Based on the evaluation of the evolution of agricultural activities in the rural communities of Markazi province, some suggestions are provided related to the policies. Evaluation of the factors affecting the agricultural situation and the rural evolution of the provinces indicated that these changes are mainly related to the lack of a single structure and organization, leading to the evacuation of a large number of rural settlements. As a guardian of villages in the country, the institutional multiplier that follows and supports this sector has caused many conflicts in policy making and much interference with the national and regional evolution plans. Therefore, an independent structure with the same decision-making and policy-making power could be established to help effectively solve the problems in rural communities. Given the implementation phase, some reforms in the rural functions are essential for enacting important reforms in the rural structure. Based on the findings, the indicators related to land and water resorces, as two important agricultural factors, became problematic during periods under study. However, more attention should be paid to the agriculture sector. The diversification of economic activities in rural areas, if targeted and related to the characteristics of each region, could have a significant share in creating employment, leading to the increased income and the improved livelihood of the villagers.

\section{References}

Anríquez E., Stamouli K. (2007): Rural development and poverty reduction: Is agriculture still the key? Electronic Journal of Agricultural and Development Economics, Agricultural Development Economics Division (ESA) FAO, 4(1): 546.

Balestrieri M. (2014): Rurality and competitiveness, some observations on the local area: The case of the Sardinian Region. International Journal of Rural Management, 10(2): 173- 197.

Berry K.A., Markee N.L., Fowler N., Giewat G.R. (2010): Interpreting what is rural and urban for western U.S. counties. The Professional Geographer, 52(1): 13.

Ebrahimpour M. (2004): The relationship between population density and depth level of cultivation. Journal of Rural and Development, 7(4): 21-49. (in Persian).

Eupen M.V., Metzger M.J., Perez Soba M., Verborg P.H., van Doorn A., Bunce. R.G.H. (2012): A rural typology for strategic European policies. Land Use Policy, 29(3): 473-482.

Feli S., Pezeshki Rad G.R., Sedighi H., Shahbazi E., Qureishi Abhari S.J. (2012): Structural Changes in Iranians Agriculture: A Perspective to 2025. Journal of Rural and Development, 15(3): 21-39. (in Persian).

Ghasemi Ardahaei A. (2008): Internal migration flows and immigrant characteristics by province. Tehran, Census Institute. (in Persian). 
Management Theory and Studies for Rural Business and Infrastructure Development

eISSN 2345-0355. 2021. Vol. 43. No. 3: 390-402

Article DOI: https://doi.org/10.15544/mts.2021.36

Ghasemi V. (2010): Modeling structural equation in social research using AMOS graphics, Tehran. Sociologist Publishing. (in Persian).

Guastella G., Pareglio S. (2016): Sustainable development of rural areas: using urban patterns to map the agricultural systems. In: the Sustainability of Well-Being International Forum, Florence.

Gulumser A.A., Levent T.B., Nijkamp P. (2006): Turkey's rurality: A comparative analysis at the EU level. In: the 46th Congress of the European Regional Science Association, Enlargement, Southern Europe and the Mediterranean, Greece.

Johansen P.H., Nielsen, N.C. (2012): Bridging between the regional degree and the community approaches to rurality: A suggestion for a definition of rurality for everyday use. Land Use Policy, 29(4): 781-788.

Karami A., Rastegari, H. (2018): Measuring and analyzing agricultural development of Iran using artificial neural network. Journal of Regional Planning, 8(30): 15-30. (in Persian).

Khosrowbeygi Borchaloei R. (2016): Government community and rural tourism in Iran reflection on renewal of dialogue and conflict between national and local stakeholders. Journal of geography, 4(49): 115-132. (in Persian).

Latifeh N., Jahani, M., Jafari, H. (2016): Economic factors affecting the instability of rural settlements: a case study of villages in Damavand County. Journal of Rural and Development, 19(1): 141-161. (in Persian).

Li Y., Long H., Liu Y. (2015): Spatio-temporal pattern of China's rural development: A rurality index perspective. Journal of Rural Studies, 38: 12- 26.

Moutafi V.G. (2013): Rural space (re) produced e Practices, performances and visions: A case study from an Aegean Island. Journal of Rural Studies, 32: 103-113.

Paquette S., Domon G. (2003): Changing rurality, changing landscapes: Exploring social recomposition using a multi-scale approach. Journal of Rural Studies, 19: 425-444.

Peng L., Shaoquan L., Lian S. (2016): Spatial-temporal changes of rurality driven by urbanization and industrialization: A case study of the three Gorges reservoir area in Chongqing, China. Habitat International, 51: 124-132.

Pizzoli E. (2015): Rural development indicators for regions with different degrees of "Rurality": A statistical study. Available at http://jms.insee.fr/files/documents/2012/939_2-jms2012_S24-2_Pizzoli-acte.pdf (accessed Nov 2019).

Rezvani M.R., Sadeghlu T., Sajadi Gheidari H. (2011): Evaluation of ruralism using fuzzy TOPSIS model (Case Study: Central Villages of Khodabandeh). Journal of Rural Research, 2(1): 1-31. (in Persian).

Rousseau N. (1995): What is rurality? Occasional paper (Royal College of General Practitioners), Chapter 1.

Statistical Center of Iran (2003, 2014): Census of Agriculture. Available at https://www.amar.org.ir (in Persian).

Statistical Center of Iran (1956, 1966, 1976, 1986, 1996, 2006, 2016): Population and Housing Census. Available at https://www.amar.org.ir (in Persian). Persian).

Statistical Yearbook of Markazi Province (2015): Markazi Province Management and Planning Organization. (in

Yousefi N. (2013): Presentation and analysis of socio-economic indicators of country populations in 2011 and comparison with 2006. National Statistical Institute, Tehran. (in Persian).

Zabihi S., Farajollah Hosseini S.J., Mirdamadi S.M. (2019): Structural changes in the demographic identity of rural areas of Markazi province during 1996-2011. Journal of Geography and Environmental Planning, 30(1): 1-22 (in Persian). 